\title{
JALAN TERJAL MENUJU ASEAN ECONOMIC COMMUNITY: KEBIJAKAN PEMERINTAH DAERAH KABUPATEN BANYUMAS DI SEKTOR UMKM
}

\author{
Ayusia Sabhita Kusuma ${ }^{1}$
}

\begin{abstract}
Abstrak
ASEAN Economic Community 2015 menuntut liberalisasi perdagangan di tingkat nasional dan daerah untuk menjadi basis produksi dan pasar tunggal ASEAN. Untuk menghadapi ini, pembangunan daerah sebagai basis pembangunan nasional mesti mempersiapkan diri untuk memanfaatkan peluang dan meningkatkan daya saing ekonomi lokal. Kabupaten Banyumas adalah kabupaten yang potensial di Provinsi Jawa Tengah. Data menunjukkan bahwa sektor UMKM di Kab. Banyumas mengalami peningkatan baik dari segi jumlah usaha, penyerapan tenaga kerja, maupun nilai dari produk. Namun, permasalahan yang ditemui adalah kurang optimalnya akses pembiayaan atau modal UMKM, permasalahan di bidang pemasaran, serta kurangnya kualitas Sumber Daya Manusia. Perumusan kebijakan yang tepat guna untuk menghadapi permasalahan-permasalahan di sektor UMKM tersebut, adalah syarat utama yang menunjukkan dukungan Pemerintah Daerah terhadap UMKM. Penelitian ini bertujuan untuk mengkaji efektifitas kebijakan pemerintah daerah Kab. Banyumas di sektor UMKM dalam menghadapi ASEAN Community 2015.
\end{abstract}

Kata-Kata Kunci: ASEAN Economic Community, Kebijakan, UMKM, Pembangunan Daerah

\begin{abstract}
ASEAN Economic Community in 2015 demanding the liberalization of trade at national and local levels to be the basis of production and single market of ASEAN. To face this, local development as the basis foundation for national development should prepare to optimize the opportunities and increase the competitiveness of the local economic. Banyumas district is a potential district in Central Java Province. Data shows that SMEs sector in Banyumas district has escalated its development both in terms of the number of SMEs, absorption of work forces, and the increasing value of the products. Nevertheless, the problems are less deficient access of financing or SMEs capital, marketing, and the lack of the quality of human resources. The needed of formulating right policy to face problems in SMEs sector is the main requirement which shows support form local government. This study aims to assess the effectiveness of local government policy of Banyumas district in SMEs sector in the face of ASEAN Community 2015.
\end{abstract}

Keywords: ASEAN Economic Community, Policy, Small Medium Enterprises, Local Development

\section{Pendahuluan}

Upaya untuk mentransformasikan institusi regional ASEAN ke arah yang lebih terbuka, kohesif dan integratif melalui pembentukan ASEAN Community 2015 telah dibahas pada pertemuan KTT ke-9 ASEAN di Bali tahun 2003. Tujuan dari pembentukan komunitas ASEAN tersebut untuk lebih mempererat, memperdalam dan memperluas integrasi ASEAN melalui people to people contact dalam menghadapi perkembangan konstelasi politik internasional yang semakin kompetitif. Pembentukan komunitas ASEAN 2015 diimplementasikan melalui 3 pilar; Komunitas Politik dan Keamanan ASEAN (ASEAN Political-Security Community), Komunitas Ekonomi ASEAN (ASEAN Economic Community), serta Komunitas

\footnotetext{
${ }^{1}$ Staf pengajar Jurusan Hubungan Internasional, FISIP Universitas Jenderal Soedirman.
} 
Jalan Terjal Menuju ASEAN Economic Community: Kebijakan Pemerintah Kabupaten Banyumas di Sektor UMKM

Sosial Budaya ASEAN (ASEAN SocioCultural Community) (ASEAN, 2009).

Khusus bidang ekonomi, melalui ASEAN Economic Community (AEC) 2015, ASEAN berupaya meningkatkan integrasi ekonomi di kawasan untuk menjadi basis produksi dan pasar tunggal. Melalui AEC, negara-negara di ASEAN diharapkan dapat menjamin bebasnya pergerakan barang, jasa, modal, investasi, pelaku usaha dan tenaga kerja ahli di Asia Tenggara. Langkah ini merupakan salah satu karakteristik utama yang dituangkan dalam cetak biru AEC sebagai berikut; mewujudkan perekonomian yang kompetitif, keadilan dalam pembangunan ekonomi, serta integrasi dengan perekonomian global (ASEAN, 2009). Cetak biru ini menunjukkan bahwa negara-negara di ASEAN dituntut untuk mempunyai kesiapan dan daya saing dalam menghadapi pasar tunggal ASEAN.

Tentu saja, pasar tunggal ASEAN tersebut dapat menjadi peluang sekaligus tantangan bagi Indonesia baik pusat dan daerah dalam konteks daya saing dan kesiapan. Perlu kita ketahui bahwa pembangunan ekonomi daerah merupakan bagian integral atau penopang pembangunan ekonomi nasional. Merujuk UU No.32 tahun 2004, daerah/local region diberi kewenangan seluas-luasnya untuk mengatur dan mengelola daerah sendiri beserta sumber daya yang ada untuk meningkatkan kesejahteraan masyarakat lokal.

Dalam konteks AEC, daerah melalui pemerintahannya diberi kewenangan secara mutlak untuk menyiapkan diri, memaksimalkan potensi dan keunggulan daerah dalam menghadapi pasar tunggal ASEAN. Termasuk menangkap peluang sebesar-besarnya agar dapat bersaing dengan daerah-daerah lain di Indonesia dan seluruh negara di Asia Tenggara.

Sejak pemerintah Indonesia menyetujui skema AEC diterapkan di Indonesia, pusat dan daerah seperti digenjot untuk mengikuti ritme pasar bebas ASEAN. Namun satu hal yang harus diingat, akselerasi ekonomi pasar bebas tersebut harus selaras dengan semangat ekonomi kerakyatan. Menghadapi persaingan dalam AEC, perekonomian daerah perlu ditingkatkan dan dijaga secara berkelanjutan terutama perekonomian di sektor riil yang langsung menyentuh masyarakat lapis bawah. Hal ini merujuk pada konstitusi Indonesia melalui UUD 1945 pasal 33 yang menyebutkan bahwa kebijakan perekonomian Indonesia mesti berpijak pada ekonomi kerakyatan.

Oleh karena itu dukungan dan sokongan pemerintah daerah seharusnya lebih besar kepada lokus-lokus ekonomi mikro, kecil dan menengah. Peran dari sektor Usaha Mikro, Kecil dan Menengah (UMKM) di Indonesia termasuk besar, terutamanya menghadapi gempuran krisis moneter atau dalam upaya pemulihan ekonomi paska krisis moneter. Selain itu pemberdayaan sektor UMKM ini sangat strategis untuk menggerakkan 
perekonomian masyarakat lapis bawah yang menjadi masyarakat mayoritas, upaya mengurangi pengangguran atau menyerap tenaga kerja serta menggalakkan kemandirian masyarakat.

Perlu diketahui bahwa jumlah UMKM di Kabupaten Banyumas mengalami peningkatan baik dari segi jumlah usaha, penyerapan tenaga kerja, maupun nilai dari produk (Pemkab Banyumas 2009). Jumlah industri kecil meningkat cukup baik, yaitu sebanyak 2.051 unit pada tahun 2009 meningkat menjadi sebesar 2.085 unit pada tahun 2013. Jumlah tenaga kerja yang terserap dalam kegiatan industri kecil pun meningkat yaitu sebesar 7.802 orang pada tahun 2009 dan meningkat pada tahun 2013 sebesar 8.083 orang. Kondisi ini mencerminkan bahwa iklim usaha di Kabupaten Banyumas semakin baik (Bappeda, 2014).

Namun begitu, potensi yang baik di bidang UMKM tersebut masih mempunyai permasalahan mendasar, antara lain masih lemahnya akses UMKM terhadap pembiayaan untuk peningkatan modal usaha, terutama akses pada lembaga keuangan atau perbankan, permasalahan di bidang distribusi atau pemasaran, serta kualitas Sumber Daya Manusia yang masih kurang baik dari segi tingkat pendidikan maupun tingkat keahlian (Wawancara dengan Yusuf, 2016).

Oleh karena itu, dibutuhkan peran aktif pemerintah daerah dalam merumuskan kebijakan yang tepat guna. Hal ini agar lebih menguatkan sektor UMKM, mendukung peningkatan pembangunan daerah secara berkelanjutan dalam menghadapi gempuran AEC 2015. Kebijakan pemerintah daerah di sektor UMKM yang dimaksud adalah tidak saja yang berkenaan dengan dukungan terhadap akses permodalan atau pendanaan, tetapi juga dukungan pada akses pasar atau pemasaran, dukungan pendidikan dan pelatihan terutama dalam peningkatan kualitas SDM, serta dukungan untuk mendapatkan teknologi komunikasi dan informasi yang tepat guna.

Penelitian ini dirancang oleh penulis untuk melakukan analisis pada kebijakan pemerintah daerah Kabupaten Banyumas pada sektor UMKM untuk melihat kondisi awal serta proyeksi ke depan dalam menghadapi ASEAN Community.

\section{Landasan Konseptual}

\section{Konsep Kebijakan Publik}

Kajian mengenai kebijakan publik menekankan pada tahapan-tahapan seperti formulasi kebijakan, adopsi kebijakan, implementasi kebijakan, hingga evaluasi kebijakan.

Dunn (2003) menguraikan lima proses dalam melakukan analisis kebijakan publik. Pertama, melakukan formulasi masalah (problem formulation). Pemetaan dan identifikasi masalah diperlukan dalam tahap pertama untuk kemudian dimasukkan jadi agenda kerja. Kedua, melakukan formulasi kebijakan (formulation). Formulasi kebijakan 
ini berkaitan dengan proses pemilihan solusi atau alternatif penyelesaian masalah oleh partisipan atau mereka yang menjadi bagian dari perumus kebijakan. Ketiga, tahap penentuan kebijakan (adoption), sebagai tindak lanjut formulasi kebijakan. Adopsi ini sudah menyangkut bagaimana nanti penetapan hasil dari pilihan-pilihan tersebut. Di tahap ini juga perlu persiapan syarat dan kriteria kebijakan yang dipilih, isi kebijakan, siapa yang melaksanakan, serta strategi pelaksanaan. Keempat, tahap implementasi (implementation). Tahap ini mencakup teknis pelaksaan kebijakan, termasuk siapa yang terlibat dalam implementasi, pembagian kerja, serta mulai diawasi dampak dari pelaksaan kebijakan. Kelima, tahap terakhir yaitu evaluasi (evaluation). Melalui tahap ini mulai diukur tingkat keberhasilan atau dampak dari kebijakan yang dikeluarkan. Di tahap ini juga dipertanyakan ada tidaknya tuntutan untuk melakukan perubahan atau pembatalan.

Berdasarkan penjelasan Dunn diatas, maka analisis kebijakan dapat disederhanakan menjadi serangkaian proses atau prosedur mencari-tahu, menentukan, dan menelaah kebijakan dengan berpatokan pada metode tertentu. Prosedur peramalan akan menghasilkan wujud kebijakan, rekomendasi akan melahirkan aksi kebijakan, pemantauan akan menghasilkan hasil-hasil kebijakan, serta evaluasi akan melahirkan kinerja dari implementasi kebijakan.

Pendapat yang kurang lebih sama, juga dinyatakan Budi Winarno (2012: 252), bahwa kebijakan publik jarang dipertahankan dalam bentuk yang sama sebagaimana di awal. Sebaliknya, kebijakan publik secara dinamis bisa berkembang. Harapannya akan terjadi perbaikan terhadap kebijakan tersebut. Faktorfaktor yang mempengaruhi perbaikan kebijakan meliputi; pertama, sejauh mana kebijakan awal dinilai mampu memecahkan persoalan-persoalan publik. Sedangkan evaluasi dilakukan untuk untuk melihat sejauh mana kebijakan yang dijalankan tersebut meraih dampak yang diinginkan. Kedua, kemampuan seperti apa sehingga kebijakankebijakan bisa dikelola. Ketiga, kelemahan apa sekiranya yang timbul selama proses implementasi kebijakan berlangsung. Pertanyaannya adalah, bagaimana melakukan analisis evaluasi kebijakan publik? Evaluasi ialah proses yang dilakukan untuk menilai, mengukur, serta menimbang ketercapaian tujuan dan manfaat sebuah kebijakan atau manfaat dari sebuah kebijakan. Evaluasi diperlukan untuk melihat ada tidaknya kesenjangan antara harapan dengan kenyataan. Sehingga lebih lanjut, evaluasi kebijakan publik dapat dipahami melalui tiga lingkup, yaitu evaluasi perumusan kebijakan, evaluasi implementasi kebijakan, dan evaluasi lingkungan kebijakan (Dwijowijoto, 2003).

\section{Konsep ASEAN Economic Community}

Pemimpin ASEAN mendeklarasikan Road Map 2009-2015 yang didalamnya berisi 
mengenai Community Blue Prints : Economic (AEC), Politic-Security (APSC), Sosio-Culture (ASCC) yang merupakan dasar dari ASEAN Community 2015. Masyarakat ASEAN bertujuan untuk menciptakan sebuah masyarakat yang berpandangan maju, hidup dalam lingkungan yang damai, stabil, dan makmur, yang dipersatukan oleh hubungan kemitraan secara dinamis serta menciptakan masyarakat yang saling peduli (ASEAN, 2009).

Salah satu yang paling banyak menyita perhatian dan dicermati kehadirannya adalah pemberlakuan ASEAN Economic Community (Masyarakat Ekonomi ASEAN/MEA). AEC merupakan realisasi pasar bebas di Asia Tenggara yang sebelumnya telah disebut dalam Framework Agreement on Enhancing ASEAN Economic Cooperation pada tahun 1992. Pemberlakuan AEC 2015 bertujuan untuk menciptakan pasar tunggal dan basis produksi yang stabil, makmur, berdaya saing tinggi, dan secara ekonomi terintegrasi dengan regulasi efektif untuk perdagangan dan investasi, yang di dalamnya terdapat arus bebas lalu lintas barang, jasa, investasi, dan modal serta difasilitasinya kebebasan pergerakan pelaku usaha dan tenaga kerja, serta meningkatkan daya saing UMKM.

Implementasi AEC 2015 akan berfokus pada 12 sektor prioritas, yang terdiri atas 7 (tujuh) sektor barang (industri pertanian, peralatan elektonik, otomotif, perikanan, industri berbasis karet, industri berbasis kayu, dan tekstil) dan 5 (lima) sektor jasa (transportasi udara, pelayanan kesehatan, pariwisata, logistik, dan industri teknologi informasi atau e-ASEAN). Implementasi AEC ini dapat memberikan dampak positif maupun negatif bagi pelaku usaha di Indonesia, terutama bagi UMKM. Dampak positif yang ada antara lain adalah terciptanya pasar internasional yang lebih luas, sementara dampak negatif yang harus diantisipasi adalah ketidakmampuan para pelaku usaha (UMKM) dalam menghadapi persaingan pasar internasional yang akan semakin tinggi.

\section{Metode Penelitian}

Penelitian ini menggunakan metode kualitatif, sedangkan analisis yang digunakan dalam penelitian ini adalah analisis deskriptif yaitu analisis dengan mendasarkan pada data primer dan sekunder terkait dengan kebijakan Pemda Banyumas di sektor UMKM dalam menghadapi Masyarakat Ekonomi ASEAN/ MEA (ASEAN Economic Community/AEC) 2015 dimana dari hasil pembahasan kemudian diambil kesimpulan dan rekomendasi. Penelitian ini juga dikembangkan dengan menggunakan pendekatan kajian literatur atau studi pustaka. Pendekatan teori atau konsep dilakukan dengan merujuk pada beberapa sumber seperti buku, jurnal ilmiah, dan media internet.

Data yang digunakan dalam penelitian ini adalah data primer dan data sekunder. Data primer diperoleh melalui wawancara mendalam 
untuk mendapatkan keterangan yang lengkap dari pihak-pihak yang mengetahui dengan pasti atau berhubungan erat dengan UMKM dan proses pengembangannya. Adapun pihak yang dijadikan sumber data primer di Kabupaten Banyumas adalah Kepala Badan Perencanaan dan Pembangunan Daerah (BAPPEDA). Hal ini untuk mengetahui rencana prioritas kebijakan pembangunan daerah khususnya yang berhubungan dengan pengembangan UMKM, Kepala Dinas Perindustrian, Perdagangan dan Koperasi untuk mengetahui perkembangan kebijakan di sektor UMKM, serta pengelola UMKM Center di Kabupaten Banyumas. Sedangkan untuk memperoleh gambaran dukungan sektor keuangan terhadap UMKM maka Bank Indonesia dan Bank-bank swasta lainnya dipilih menjadi sumber data primer untuk mengetahui kebijakan penyaluran keuangan untuk UMKM.

Disamping itu, untuk memperkaya sumber data primer di Kabupaten Banyumas maka dilakukan wawancara dengan pengurus Kamar Dagang dan Industri Daerah. Hal ini dilakukan untuk melakukan mengetahui apakah kebijakan pemerintah dalam memberikan dukungan permodalan bagi UMKM ini dapat dirasakan para pelaku usaha dan juga harapan-harapan terhadap kebijakan yang sedang atau akan diterapkan pada sektor UMKM Banyumas. Sementara itu data sekunder diperoleh melalui studi literatur dari hasil penelitian yang dilakukan sebelumnya, buku, internet dan data yang diperoleh Badan
Pusat Statistik.

\section{Teknik Pengumpulan data}

Secara teoritik, setiap penelitian dalam mengumpulkan data menggunakan satu atau lebih teknik. Sebagai penelitian kualitatif, penelitian ini merupakan field research yang menggunakan teknik pengumpulan data dimulai dengan ide-ide atau topik yang diformulasikan secara longgar. Kemudian dilanjutkan dengan wawancara langsung dan mendalam (in-depth) dengan menggunakan pedoman. Untuk itu dilakukan observasi dengan membuat catatan-catatan secara detail tentang data-data yang diperoleh dalam setiap harinya. Selama itu pula dipertimbangkan apa yang diobservasi dan menyaring serta memfokuskan pada ide-ide signifikan. Selanjutnya diluar lapangan setiap data yang diperoleh dikaji kembali dan mempersiapkan lapporannya. Sedangkan data sekunder dikumpulkan melalui penelitian pustaka dengan cara mencatat dan mendokumentasikan berbagai data yang terkait dengan masalah penelitian. Penelitian pustaka ini antara lain meliputi: hasil penelitian terdahulu, buku, jurnal, artikel dan sebagainya yang relevan dengan tujuan penelitian.

\section{Metode Analisis Data}

Dalam melakukan analisis terhadap data yang sudah terkumpul, peneliti merujuk pada pemikiran dari Miles dan Huberman (1984). Peneliti melakukan pereduksian data dengan melakukan penyederhanaan dan pengabstrakan. Pereduksian data ini bertujuan 
untuk menggolongkan, mengarahkan, membuang data yang dianggap tidak diperlukan serta mengorganisir data tersebut. Kemudian dilakukan transformasi terhadap data-data yang diperoleh di lapangan maupun yang diperoleh peneliti sebelum terjun ke lapangan, demikian terus dilakukan hingga dapat ditarik kesimpulan-kesimpulan.

a. Memaparkan materi-materi data yang sudah direduksi dan ditransformasikan dalam bentuk penjabaran materi yang diorganisir, dilengkapi dengan ringkasan berstruktur.

b. Penarikan kesimpulan, yaitu peneliti melakukan penafsiran-penafsiran tertentu terhadap materi yang sudah dijabarkan dengan mencatat keteraturan, pola-pola atau konfigurasi lain yang mungkin muncul. Penggunaan kerangka konseptual yang digunakan dalam penelitian ini sangat membantu dalam mengkonstruksikan penafsiran-penafsiran tersebut.

\section{Pembahasan}

Dalam RPJM Daerah Kabupaten Banyumas tahun 2008-2013, tujuan pemerintah daerah adalah memajukan pembangunan industri, perdagangan, koperasi dan usaha kecil menengah agar maju dan berdaya saing. Merujuk dengan tujuan tersebut, perlu peran aktif pemerintah daerah dalam merumuskan kebijakan yang tepat untuk lebih memberdayakan atau menguatkan sektor UMKM. Menghadapi AEC 2015, kebijakan - kebijakan pemerintah daerah di sektor UMKM semestinya mendukung pertumbuhan UMKM yang sehat. Dalam hal ini yang dimaksud adalah tidak saja berkenaan dengan dukungan terhadap akses permodalan atau pendanaan, tetapi juga dukungan pada akses pasar atau pemasaran, dukungan pendidikan dan pelatihan terutama dalam peningkatan kualitas SDM, serta dukungan untuk mendapatkan teknologi komunikasi dan informasi yang tepat guna.

Dari segi kebijakan, pemerintah daerah Kab. Banyumas mempunyai regulasi terkait pengembangan sektor UMKM namun hanya sedikit sekali. Pemerintah Daerah Kabupaten Banyumas sudah mengeluarkan produk kebijakan terkait pengembangan UMKM yang selaras dengan tujuan RPJMD Kabupaten Banyumas Tahun 2008-2013 yaitu salah satunya adalah Peraturan Bupati Banyumas Nomor 18 Tahun 2008 tentang Penyaluran Pinjaman Dana Kredit Bergulir Perkuatan Permodalan UMKM. Dalam peraturan Bupati ini ditulis bahwa diadakan penyaluran bantuan sebesar Rp. 150.000.000,00 per UMKM baik yang tergabung dalam bentuk kelompok maupun perorangan melalui Bank pelaksana yaitu PD.BPR.BKK Purwokerto Utara, PD. BKK Patikraja, PD. BKK Purwokerto Selatan dan PD. BKK. Sumbang.

Penyaluran pinjaman ini bertujuan untuk memperkuat aspek permodalan pada UMKM, mengembangkan produktifitas UMKM dan mengembangkan unit simpan 
Jalan Terjal Menuju ASEAN Economic Community: Ke-

bijakan Pemerintah Kabupaten Banyumas di Sektor UMKM

pinjam. Selain itu, pemerintah daerah juga mengeluarkan Peraturan Daerah Kabupaten Banyumas Nomor 3 Tahun 2010 tentang Penataan dan Pembinaan Pasar Tradisional, Pusat Perbelanjaan dan Toko Modern. Peraturan Daerah ini dimaksudkan untuk memberdayakan Pasar Tradisional agar dapat tumbuh dan berkembang secara serasi bersamaan dengan berkembangnya usaha perdagangan eceran yang berbentuk pusat perbelanjaan dan pasar modern. Tujuan utama dari Perda ini adalah untuk melindungi sektor usaha kecil dan menengah masyarakat. secara serasi bersamaan dengan berkembangnya usaha perdagangan eceran yang berbentuk pusat perbelanjaan dan pasar modern. Namun implementasi dari peraturan-peraturan ini masih kurang optimal disebabkan beberapa kendala teknis maupun struktural. Sebagai contoh dalam Perda No. 3 Tahun 2010, perda tersebut tidak bisa dilaksanakan karena ada kebijakan moratorium sehingga perlu ada revisi.

Meskipun pengembangan usaha kecil dan menengah juga termaktub dalam tujuan RPJMD Tahun 2008 hingga 2016, hal ini membutuhkan regulasi-regulasi di tingkatan teknis pelaksanaan dan pengelolaan UMKM yang lebih komprehensif sebagai landasan pergerakan dan pengelolaan UMKM.

Dinas Perindustrian, Perdagangan dan Koperasi dalam hal ini diwakili oleh Ibu Sri Hastutik dalam wawancaranya bersama kami memberitahukan bahwa pemerintah melalui
Disperindagkop, telah menelurkan kebijakan mengenai pengembangan UMKM melalui OVOP (One Village One Product), dimana pilot project nya adalah di Kec. Sumpiuh Kab.Banyumas. Pemerintah juga telah mendirikan dan mengelola UMKM Center "Hasta Pratista" sebagai sarana promosi UMKM. Di UMKM Center ini ada sekitar 66 ribu lebih UMKM yang ikut berpartisipasi dan sudah mendisplay beragam hasil dan produk UMKM di bidang makanan dan kerajinan tangan.

Disperindagkop juga mengklaim melaksanakan pelatihan-pelatihan seperti pengemasan atau packaging, serta melaksanakan program pembiayaan bagi UMKM yang tidak berbadan hukum dan program hibah bagi UMKM yang berbadan hukum sebagai bukti pelaksanaan Peraturan Bupati No. 18 tahun 2008. Selain itu Disperindagkop juga memberikan support pada UMKM melalui promosi produk-produk UMKM secara gratis melalui pameran dan UMKM Center Hasta Pratista. Namun, Disperindagkop mengakui bahwa kebijakan di sektor UMKM kabupaten Banyumas belum mengarah pada visi dan strategi menghadapi kompetisi ekonomi era ASEAN Economic Community. Pengembangan sektor UMKM hanya didasarkan pada pelaksanaan program pembangunan daerah terutama dalam rangka peningkatan perekonomian.

Dalam analisa kebijakan publik, pemerintah Kabupaten Banyumas sudah 
melakukan tahapan terkait penyusunan, implementasi hingga evaluasi kebijakan sektor UMKM. Melalui tahapan formulasi masalah, pemerintah daerah Kab. Banyumas memahami perlunya pengembangan sektor ekonomi mikro, kecil dan menengah agar berdaya saing. Kebijakan ini diimplementasikan melalui misalnya Peraturan Bupati Banyumas Nomor 18 Tahun 2008 tentang Penyaluran Pinjaman Dana Kredit Bergulir Perkuatan Permodalan UMKM. Namun dalam tahap formulasi masalah, belum ada pemetaan yang memadai tentang persoalan yang dihadapi sektor UMKM di Kab. Banyumas. Data yang ada hanya sebatas jumlah unit usaha, jumlah tenaga kerja, dan nilai produk yang dihasilkan. Hal ini berjalin kelindan dengan tahapan evaluasi kebijakan yang juga penulis nilai masih kurang.

Perkembangan visi misi Kabupaten Banyumas dengan slogan "Better Banyumas" tidak diimbangi dengan serangkaian upaya internasionalisasi produk-produk atau potensi daerah. Kurangnya pemahaman tentang ASEAN Community 2015 baik di tingkatan pengampu kebijakan daerah hingga ke level masyarakat menunjukkan kekurangan informasi. Hal ini tentu saja mempengaruhi pembuatan kebijakan di tingkatan daerah, baik kebijakan bidang ekonomi, sosial budaya maupun politik dan keamanan. Baik dari segi pemetaan permasalahan hingga penentuan kebijakan nantinya. Kebijakan yang dihasilkan dari pengampu di tingkatan daerah kemudian kurang memperhatikan aspek peluang dan tantangan daerah dalam menghadapi ASEAN Community. Dalam Rencana Kerja BAPPEDA (Banyumaskab, 2015), BAPPEDA tidak mengadaptasi semangat ASEAN Community 2015, hanya termaktub semangat capaian program MDGs (Millenium Development Goals).

Dalam tahapan penentuan kebijakan, Rencana Kerja BAPPEDA 2015 juga menyebutkan bahwa proses perencanaan pembangunan daerah harus mampu mengakomodir secara obyektif berbagai kebutuhan dan aspirasi masyarakat. Sehingga, seharusnya dalam pengambilan keputusan, memerlukan keterlibatan masyarakat. Pelaksanaan dari rencana kerja ini masih abstrak karena dalam konteks UMKM, pelakupelaku usaha UMKM kurang diajak berpartisipasi aktif terutama dalam pengembangan usaha mereka. Hal ini berimbas pada implementasi di lapangan. UMKM Hasta Pratista misalnya, yang digadang-gadang menjadi pusat kegiatan UMKM, kurang mendapatkan respon positif bagi pelaku UMKM. Hal ini dikarenakan, kurangnya sosialisasi, kurangnya mengakomodir kebutuhan UMKM (terutama transportasi dan logistic), serta kurangnya manajemen baik dalam pemasaran, pelatihan hingga akses permodalan (Wawancara dengan Yusuf, 2015). Meskipun begitu, Peraturan Bupati tentang penyaluran pinjaman dana kredit bergulir kepada UMKM patut diapresiasi. 
Permasalahannya kemudian adalah, kurangnya SDM dalam manajemen pengelolaan keuangan maupun dalam manajemen usaha. Hal ini menjadi hambatan besar bagi UMKM untuk survive dan secara berkelanjutan, mengembangkan UMKMnya. Terutama UMKM kecil di daerah-daerah terpelosok Banyumas yang sebenarnya mempunyai potensi besar untuk berkembang, menjadi kurang didukung perkembangannya oleh Pemerintah. Terbatasnya akses transportasi, logistic, manajemen keuangan serta manajemen pemasaran, membuat UMKM di daerah-daerah tidak mampu bersaing di tingkat local.

Dalam percaturan AEC, manajemen pemasaran menjadi alat utama dalam peningkatan daya saing produk-produk UMKM. Produksi Gula Kelapa Kabupaten Banyumas, Minyak Atsiri serta serangkaian produk lokal sebenarnya sudah berkualitas ekspor bahkan sudah diekspor hingga ke benua Eropa. Namun, pasar regional ASEAN masih sangat kurang dimanfaatkan dalam skema AEC. Hal ini menjadi kendala bagi upaya pemasaran produk-produk lokal Banyumas ke negara-negara di Asia Tenggara. Untuk itulah evaluasi kebijakan sangat penting terutamanya agar selalu mengikuti tren global atau regional dalam skema liberalisasi pasar yang tidak bisa kita tolak. Hal ini bukan bertujuan untuk penghambaan terhadap pasar, namun justru bisa sebaliknya, tetap survive dalam gempuran globalisasi ekonomi.
Lebih lanjut menurut Yusuf Meri Triadi, pengelola UMKM Center Hasta Pratista, UMKM center kurang dikelola dengan baik oleh Disperindagkop, malah terkesan ditelantarkan. Hal ini disebabkan karena kurangnya sarana sosialisasi, kurang fasilitasi dan pembiayaan, kurang koordinasi antar UMKM serta pemerintah tidak menjadikan UMKM center sebagai pusat pariwisata Kab. Banyumas. Pemerintah juga secara umum kurang mempunyai visi tentang pengembangan UMKM dalam pembuatan kebijakan di tingkat daerah.

Bapak Eko Prijanto, kepala BAPPEDA Kabupaten Banyumas juga menyebutkan beberapa permasalahan terkait pengembangan UMKM di Banyumas. Eko mengakui bahwa potensi andalan Kabupaten Banyumas adalah sektor pertanian dan UMKM, terutamanya produk andalan UMKM yaitu gula kristal dan kerajinan tangan. Namun kendalanya adalah kurangnya SDM untuk meningkatkan produktivitas, selain juga faktor birokrasi, serta tidak adanya sinergi dari berbagai stakeholders dalam pengembangan UMKM dan potensi daerah tersebut. Perlu diketahui juga bahwa sebenarnya banyak sekali investor yang hendak masuk ke Banyumas. Namun permasalahan yang menghalangi antara lain, pertama, tata ruang daerah yang kurang terkelola dengan baik. Sebagai contoh, industri garmen merasa kesulitan mencari lahan di Kab. Banyumas.

Kedua, pengurusan ijin yang kurang 
mendukung iklim investasi. Birokrat takut pada ketidakpastian dan iklim usaha sehingga ijin untuk industri yang sama prosedur perijinan bisa berbeda. Ketiga, Kurangnya koordinasi antar instansi. Permasalahan yang kerap terjadi adalah ketidaksinkronan antara keinginan pemerintah dengan pengusaha. Keempat, sarana infrastruktur transportasi yang kurang mendukung. Tidak adanya bandara udara terdekat sebagai penunjang mobilisasi dan perkembangan perekonomian daerah.

Hasil wawancara kami dengan narasumber berikutnya yaitu dari KADIN (Kamar Dagang dan Industri) Kabupaten Banyumas melalui Bapak M. Alivanto menghasilkan catatan yaitu, pertama, pemikiran pelaku UMKM di Kabupaten Banyumas harus dirubah, yang tadinya hanya berorientasi profit jangka pendek (yang penting produk terjual) harus dikembangkan untuk menunjang perekonomian daerah dan mengembangkan nilai budaya lokal Banyumas. Kedua, kurangnya sosialisasi dan penyebaran informasi antara pengusaha, pemerintah daerah dan kelompok akademisi mengenai pengembangan UMKM menghadapi $A S E A N$ Economic Community dan adanya gap antara pemerintah daerah dengan pengusaha sehingga kurang terbinanya UMKM Binaan dalam persiapan menghadapi AEC. Kebijakan di tingkat pemerintah daerah dalam segi pelatihan juga belum maksimal dalam mensupport halhal teknis seperti disain merk atau pengemasan yang menarik bagi produk-produk UMKM yang sebagian besar adalah produk-produk pertanian seperti gula kristal atau minyak atsiri.

\section{Kesimpulan}

Potensi daerah Kabupaten Banyumas cukup banyak dan dapat ditingkatkan, terutamanya dalam sektor UMKM karena jiwa kewirausahaan masyarakat Kabupaten Banyumas cukup tinggi. Namun begitu, potensi yang baik di bidang UMKM tersebut masih mempunyai permasalahan mendasar, antara lain masih lemahnya akses UMKM terutamanya yang masih kecil terhadap pembiayaan untuk peningkatan modal usaha, belum lagi permasalahan di bidang distribusi atau pemasaran karena letaknya cukup terpencil, serta kualitas Sumber Daya Manusia yang masih kurang baik dari segi tingkat pendidikan maupun tingkat keahlian. Pemerintah daerah dalam hal ini Disperindagkop tidak mensupport kelangsungan dari UMKM kecil yang sebenarnya mempunyai potensi besar.

Potensi peningkatan UMKM dari segi jumlah dan penyerapan tenaga kerja memang menunjukkan tren positif, telah adanya kebijakan mengenai pengembangan UMKM di Kab. Banyumas melalui OVOP (One Village One Product). Sudah dibangunnya UMKM Center "Hasta Pratista" sebagai sarana promosi UMKM juga perlu diapresias. Akan tetapi berbicara masalah keberlanjutan, banyak 
permasalahan yang harus segera dicarikan solusi dalam pengembangan UMKM tersebut.

Utamanya adalah persepsi dan visi misi pemerintah daerah dalam pengembangan UMKM. Visi pengembangan UMKM harus didasarkan pada kondisi obyektif tidak hanya di tingkatan lokal namun juga nasional bahkan regional. Arus globalisasi barang jasa, modal dan tenaga kerja telah sedemikian masif, jika pemerintah daerah tidak bergegas mengambil peluang dan kesempatan maka akan jauh tertinggal. AEC adalah momentum untuk dipergunakan sebaik mungkin bagi pemerintah daerah dalam mengikuti kompetisi ekonomi regional.

Permasalahan yang banyak ditemukan di lapangan dalam pengembangan sektor UMKM selain kebijakan yang kurang komprehensif dan responsif, adalah kendalakendala seperti kurangnya SDM ahli, kurangnya modal usaha, kurangnya inovasi serta kurangnya koordinasi atau sinergi antara pemerintah daerah, pengusaha, akademisi dan masyarakat luas dalam upaya pengembangan UMKM ini.

Apabila semua pihak dan stakeholder mempunyai kesamaan persepsi dalam pembangunan daerah melalui pengembangan sektor UMKM, bukan tidak mungkin Kab. Banyumas menjadi barometer perekonomian di tingkat regional Jawa Tengah, nasional bahkan internasional. Mengingat banyaknya potensi daerah yang masih dapat dikembangkan dengan seoptimal mungkin dengan membawa local values Banyumas seperti industri pariwisata, wisata alam, barang kerajinan, maupun produk-produk pertanian. Selama visi misi dan persepsi pembuat kebijakan di daerah belum mengarah kesana, bukan tak mungkin jalan di hadapan semakin terjal dalam menghadapi persaingan nasional dan regional, khususnya menghadapi pasar tunggal ASEAN. 
Ayusia Sabhita Kusuma

\section{DAFTAR PUSTAKA}

Association Southeast Asian Nations. 2009. Roadmap for an ASEAN Community 2009-2015. Jakarta: ASEAN Secretariat

Badan Perencanaan dan Pembangunan Daerah. Kab. Banyumas.2014. Kerangka Acuan Kerja. (tidak dipublikasikan)

Budiardjo, Miriam. 2009. Dasar-dasar Ilmu Politik. (Jakarta : PT.Gramedia Pustaka)

Dwijowijoto. 2003. Kebijakan Publik Formulasi, Implementasi, dan Evaluasi.

Jakarta: PT.ELEX Media Komputindo.

Miles, M.B, and Huberman A.M.,1984. Qualitative Data Analysis. California, Sage Publications.

Pemerintah Kabupaten Banyumas. Peraturan Daerah Kabupaten Banyumas No 7 Tahun 2009 tentang RPJMD Kab. Banyumas 2005-2025. Banyumas: Pemerintah Kabupaten Banyumas

Peraturan Bupati Banyumas Nomor 18 Tahun 2008 tentang Penyaluran Pinjaman Dana Kredit Bergulir Perkuatan Permodalan UMKM.

Syihabuddin, Abu Nur dan Dinar Saefudin. "Upaya Kesiapan Indonesia dalam Menghadapi MEA 2015 melalui Revitalisasi UMKM" dalam Economics Development Analysis Journal (EDAJ) 2 (2) (2013), Universitas Negeri Semarang, Mei 2013

Tedjasuksmana, Budianto (2014) Potret UMKM Indonesia Menghadapi Masyarakat Ekonomi ASEAN 2015. In: The 7th NCFB and Doctoral Colloquium 2014 Towards a New Indonesia Business Architecture Sub Tema: "Business And Economic Transformation Towards AEC 2015” Fakultas Bisnis dan Pascasarjana UKWMS, October, 30, 2014, Surabaya.

Tyas, A.A.W.P \& Vita Intan Safitri, “ Penguatan Sektor UMKM Sebagai Strategi Menghadapi MEA 2015”, Jurnal Ekonomi, Volume 5 Nomor 1, Mei 2014

William Dunn. 2003. Pengantar Analisis Kebijakan Publik. (Yogjakarta: Gajah Mada University Press).

Winarno, Budi. 2012. Kebijakan Publik: Teori, Proses dan Studi Kasus. Gejayan, Yogyakarta : Center for Academic Publishing Service 